\title{
Representasi Maskulinitas Dalam Iklan Televisi Pond's Men \#Lelakimasakini (Analisis Semiotika Roland Barthes Terhadap Representasi Maskulinitas)
}

\author{
Friska Dewi Yuliyanti, Atwar Bajari, Slamet Mulyana
}

Program Studi Manajemen Komunikasi, Fakultas Ilmu Komunikasi, Universitas Padjadjaran atwarbajari@gmail.com, atwarbajari@unpad.ac.id

\begin{abstract}
This research aims to know the meaning of denotation, the connotation and the myth or ideology in television commercials POND'S Men that represent the masculine with \#LelakiMasaKini edition. The method used in this research is the Semiotic analysis methods. The Semiotic analysis used in this research is the Semiotic Roland Barthes. The results of this research show that there are; meaning denote, the connotation and the myth or ideology in television commercials POND'S \#LelakiMasaKini. The results obtained from the signs of the dominant in the preview scenes that are taken in accordance with the criteria that have been determined. Advertising on Rio Dewanto version described three meaning denotes, three meaning of the connotations and three myths. On the version of the advertisement, Keenan Pearce described three meaning denotes, three the meaning of the connotations and three myths or ideologies and on the version of the Marshall Sastra described three meaning denotes, three the meaning of the connotations and 3 myths or ideologies. Concluded the side or the form of masculinity is promoted of the physical appearance of the type of men who tend to metrosexual, the dream of women, the leader success, lack men who think creatively and have hobbies.
\end{abstract}

Keywords: denotation, konotation, masculinity, myth, semiotics

\begin{abstract}
Abstrak
Penelitian ini bertujuan untuk mengetahui makna denotasi, konotasi serta mitos atau ideologi dalam iklan televisi POND'S Men yang merepresentasikan maskulinitas dengan edisi \#LelakiMasaKini. Metode yang digunakan dalam penelitian ini adalah metode analisis semiotik. Analisis Semiotik yang digunakan dalam penelitian ini adalah analisis semiotik Roland Barthes. Hasil dari penelitian ini menunjukkan bahwa terdapat makna denotasi, konotasi serta mitos atau ideologi pada iklan televisi POND'S Men \#LelakiMasaKini. Hasil itu diperoleh dari tanda-tanda dominan pada cuplikan adeganadegan yang diambil sesuai dengan kriteria yang telah ditentukan. Pada iklan versi Rio Dewanto digambarkan 3 makna denotasi, 3 makna konotasi, dan 3 mitos. Pada iklan versi Keenan Pearce digambarkan 3 makna denotasi, 3 makna konotasi dan 3 mitos atau ideologi dan pada versi Marshall Sastra digambarkan 3 makna denotasi, 3 makna konotasi dan 3 mitos atau ideologi. Disimpulkan sisi atau bentuk maskulinitas yang dipromosikan adalah tampilan fisik tipe laki-laki yang cenderung metroseksual, dambaan wanita, pemimpin yang cerdas dengan kesuksesan, lak-laki yang berpikir kreatif dan memiliki hobi.
\end{abstract}

Kata kunci: denotasi, konotasi, maskulinitas, mitos, semiotika 
Friska Dewi Yuliyanti, Atwar Bajari, Slamet Mulyana: Representasi Maskulinitas Dalam Iklan Televisi Pond's Men \#Lelakimasakini (Analisis Semiotika Roland Barthes Terhadap Representasi Maskulinitas)

\section{Pendahuluan}

Laki-laki tidak pernah lepas dari kata maskulin, dan 'macho'. Maskulinitas pada laki-laki memang sudah lekat ditambah lagi dengan tayangan di media yang memperlihatkan kemaskulinitasan laki-laki dari segi kekuatan dan cara laki-laki berdandan (grooming). Walaupun, maskulinitas bukan hanya meliputi bagian fisik saja namun, dapat mempengaruhi pemikiran tentang laki-laki, gender dan hirarki sosial (Connel dan Messershmidt, n.d.).

Maskulin adalah sifat-sifat yang dipercaya lekat dengan laki-laki dan maskulinitas dibentuk oleh budaya dengan ciri-ciri ideal laki-laki. Media menampilkan maskulinitas dengan mengonstruksikan imaji seorang laki-laki berkulit putih dan berstatus kelas menengah serta membuat seperangkat atribut dan aturan normatif yang bertentangan dengan jenis maskulinitas lainnya. Tindakan itu disebut dengan maskulinitas hegemonis.

Penggambaran media yang menampilkan laki-laki ideal seperti kriteria di tersebut atas, secara tidak sadar memicu para laki-laki berusaha untuk membuat dirinya seperti yang ditampilkan di berbagai media. Agar mereka tampak sebagai laki-laki ideal. Iklan, dalam hal ini merupakan sebuah penyebaran informasi yang cukup mudah dikonsumsi oleh masyarakat. Bukan hanya sekadar informasi mengenai produk saja melainkan sebagai media yang dapat menawarkan ideologi, gaya hidup dan imaji mengenai produk.

Pada tahun 1900-an representasi tentang maskulinitas dan laki-laki berubah karena sesuai dengan berkembangnya zaman yang memasuki era globalisasi. Konstruksi diri para laki-laki mengalami adaptasi yang baru dan disebut dengan new masculinity. Menurut Mark Simpson (2002), seperti yang dikutip dari Triwidiastuty dan Kahija (2015) pengonstruksian ini disebut dengan karakter laki-laki metroseksual. Tipe metroseksual adalah laki-laki muda dengan banyak uang yang mereka habiskan. Kaum metroseksual biasanya berprofesi dalam modelling, media, musik pop, atau sport. Mereka "cantik" dimanapun mereka berada.

Sesuai dengan perkembangan zaman, iklan produk khusus perawatan lakilaki bermunculan. Iklan-iklan produk perawatan wajah untuk laki-laki ini memiliki banyak tema, seperti tema olahraga, otomotif, yang mengidentikkan laki-laki dengan kekuatan fisik lainnya. Maka dengan adanya produk perawatan wajah ini tidak ada bedanya iklan rokok, minuman berenergi dan otomotif karena sama-sama merepresentasikan maskulinitas di dalam iklannya.

Pada iklan POND'S Men. POND'S pada awalnya hanya sebuah produk perawatan kulit untuk wanita saja sejak 1846. Pada tahun 2013 POND'S mengeluarkan produk barunya yaitu POND'S Men. Iklan produk POND'S Men merupakan sebuah produk perawatan kulit wajah untuk laki-laki yang diformulasikan khusus untuk mencerahkan serta memberikan energi bagi kulit wajah laki-laki sehingga mereka selalu siap menjalankan hari-hari sesibuk dengan penuh energi. POND'S Men menampilkan \#LelakiMasaKini sebagai representasi maskulinitas laki-laki pada zaman sekarang. \#LelakiMasaKini dipilih melihat banyaknya laki-laki yang modern saat ini, bukan hanya seputar dandanannya saja namun, cara berpikir sebagai lelaki masa kini. 
Pemilihan iklan POND'S Men\#LelakiMasaKini sebagai objek penelitian didasari oleh penampilan laki-laki yang cenderung dikatakan macho dan ideal pada zaman sekarang, penampilan laki-laki masa kini yang rapi, stylish dan memperhatikan kebersihan wajahnya. Hal ini dibuktikan dengan penampilan model laki-laki tersebut dalam kehidupan sehari-harinya. Peneliti berupaya mencoba mengungkapkan representasi maskulinitas lain dalam iklan POND'S Men.

Berdasarkan latar belakang tersebut, pertanyaan penelitian yang diajukan dalam adalah; (1) Bagaimana isi pesan iklan POND'S Men \#LelakiMasaKini?, (2) Bagaimana wujud maskulinitas pada iklan perawatan wajah tersebut?. Tujuan penelitian ini adalah mengkaji lebih lanjut isi pesan dalam iklan POND'S Men \#LelakiMasaKini serta membongkar maskulinitas pada iklan perawatan wajah tersebut dengan menggunakan analisa Semiotika.

\section{Metode Penelitian}

Metodologi yang digunakan dalam penelitian ini adalah kualitatif analisis semiotika, struktural Roland Barthes. Analisis ini dipilih karena mengkaji hal gejala budaya, seperti sistem mode busana, menu makanan, bidang arsitektur, lukisan, film, iklan dan karya sastra. Semiotika Roland Barthes, membahas fenomena keseharian yang luput dari perhatian tentang representasi maskulinitas dalam iklan.

Tujuan utama penggunaan semiotika Roland Barthes untuk menganalisis media berdasarkan asumsi bahwa media dikomunikasikan melalui seperangkat tanda. Barthes memiliki tiga tahapan membongkar tanda pada media yang dianalisis yaitu; tahap denotasi, tahap konotasi dan mitos atau ideologi sebagai tahapan akhir yang merefleksikan tanda tersebut melalui sudut pandang kultur tertentu, (Kusumastutie, 2004).

\section{Hasil Penemuan dan Diskusi}

Pada bagian ini, peneliti memaparkan hasil dan pembahasan dengan menggunakan tiga versi iklan yang dikeluarkan oleh POND'S Men dengan edisi \#LelakiMasaKini. Peneliti membagi ke dalam sembilan unit analisis berdasarkan versi yang diperankan oleh model iklan. Berikut merupakan hasil analisis melalui tiga tahapan semiotika Roland Barthes, yaitu denotasi, konotasi dan mitos atau ideologi. 
Friska Dewi Yuliyanti, Atwar Bajari, Slamet Mulyana: Representasi Maskulinitas Dalam Iklan Televisi Pond's Men \#Lelakimasakini (Analisis Semiotika Roland Barthes Terhadap Representasi Maskulinitas)

\section{POND'S Men \#LelakiMasaKini versi Rio Dewanto.}

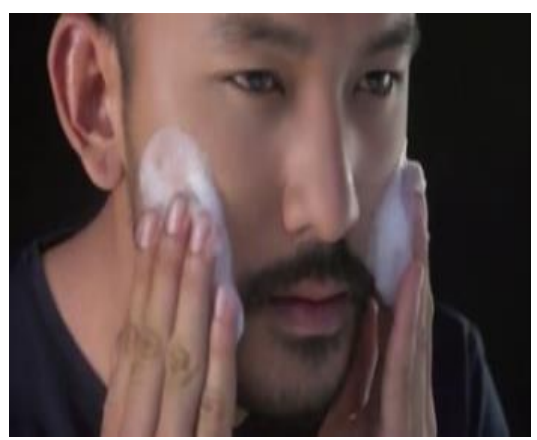

Gambar 1: Scene 1 Iklan Versi Rio Dewanto

Makna denotasi: Petanda yang berada dalam potongan gambar 1 dari iklan di atas ialah seorang laki-laki yang mencuci wajahnya dengan facial foam yang menggunakan $t$-shirt warna hitam muda, wajah dihiasi kumis dan janggut tipis dan berlatar belakangkan warna hitam yang lebih gelap. Pada adegan ini pula didukung dengan adanya audio yang berbunyi "Lelaki masa kini tahu bagaimana mengawali harinya dengan percaya diri..." Tanda yang muncul sangat jelas ialah ada serorang laki-laki yang sedang mencuci wajahnya dengan menggunakan facial foam (produk perawatan wajah).

Makna Konotasi: Percaya diri setelah mencuci wajah. Screen shot pada iklan ini menampilkan makna laki-laki yang memiliki wajah yang bersih dan segar berdasarkan kategori, adegan ini dipilih karena menghabiskan uang dan waktunya untuk perawatan diri. Wajah menjadi salah satu penunjang penampilan sebagai seorang laki-laki, untuk zaman sekarang bukan hanya perempuan saja yang memperhatikan penampilan wajah semata. Laki-laki berhak atas hal tersebut karena semakin banyak produk perawatan khusus untuk laki-laki. Bukan hanya memiliki warna kulit yang putih saja namun, harus sehat dan terlihat segar juga. Untuk mendapatkan wajah yang bersih, segar, Rio Dewanto mencuci wajahnya setiap kali ia akan beraktivitas demi menambah rasa percaya dirinya saat mengawali hari dengan diawali oleh wajah yang bersih dan segar. Menggunakan produk perawatan tidak menjadikan Rio sebagai laki-laki yang feminim, namun dengan pembawaannya tetap terlihat maskulin dengan banyak menggunakan warna baju hitam. Warna hitam menggambarkan kekuatan, maskulin, dan percaya diri.

Mitos: Menambah rasa percaya diri setelah mencuci muka. Pada dasarnya semua manusia ingat dengan kebersihan, terutama tentang kebershian pada tubuh (Savitri, 2011). Setiap orang tentunya ingat dengan kebersihan pada diri sendiri, termasuk laki-laki, yang bisa dikatakan cuek dengan penampilan namun, mengingatnya keharusan tersebut membuat mereka mau tidak mau harus memperhatikan kebersihan dirinya. Seperti kesehatan untuk wajah. Maka, bermunculan iklan produk sabun pembersih wajah seperti POND'S Men ini. Lakilaki yang memiliki perhatian lebih dengan kebersihannya termasuk ke dalam maskulinitas pada era 2000-an yaitu maskulinitas baru atau metroseksual. Laki- 
laki metrosesksual adalah mereka dari kalangan menengah atas, berdandan, dan tergabung dalam komunitas terpandang.

Mitos menambah rasa percaya diri muncul karena setelah mencuci muka timbul rasa segar yang menimbulkan rasa percaya diri untuk menjalani aktivitas sehari-hari. Selain itu. tidak ada salahnya memperhatikan kebersihan wajah demi penampilan yang lebih menarik.

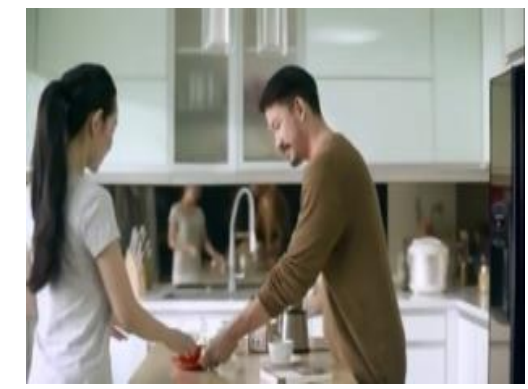

Gambar 2: Scene 2 Iklan Versi Rio Dewanto

Makna denotasi: Dapat diuraikan, petanda yang berada dalam potongan iklan di atas ialah di sebuah dapur. Digambarkan seorang laki-laki sedang menyuguhkan secangkir kopi untuk seorang wanita. Model laki-laki menggunakan $t$-shirt berwarna coklat.

Makna konotasi: Lelaki masa kini adalah lelaki yang perhatian. Screen shoot pada iklan ini menampilkan makna maskulinitas dengan model lakilaki yang disebut dengan ciri laki-laki masa kini. Berlatar belakang disebuah dapur dengan adegan membuat dan menyediakan kopi untuk wanita adalah sebuah ciri laki-laki yang menghargai wanita dan tipe laki-laki yang perhatian. Laki-laki yang menghargai wanita dan perhatian adalah laki-laki yang diidamidamkan wanita. Seganteng dan semapan laki-laki jika dia tidak memiliki kriteria sebagai laki-laki yang menghargai wanita dan perhatian bukanlah menjadi sosok yang diinginkan oleh setiap wanita. Bagi wanita ciri laki-laki dengan karakter tersebut ialah laki-laki yang sempurna dan bernilai plus.

Mitos: Lelaki masa kini adalah lelaki yang perhatian. Laki-laki dikatakan maskulin apabila ia memiliki rasa perhatian meskipun sedikit karena pada dasarnya laki-laki memiliki sifat cuek. Rasa perhatian itu bisa saja dengan rasa sopan hormat, perempuan paling suka jika ada laki-laki yang memperlakukannya seperti seorang putri. Kemaskulinitasan laki-laki akan terlihat jika ia merupakan pendengar yang baik, keahlian ini penting dan wajib dikuasi (Savitri,2011). Mendengarkan merupakan cara ampuh untuk mengikat hati perempuan, karena pada dasarnya perempuan hanya butuh untuk didengarkan saja meskipun hanya untuk hal-hal yang remeh. 
Friska Dewi Yuliyanti, Atwar Bajari, Slamet Mulyana: Representasi Maskulinitas Dalam Iklan Televisi Pond's Men \#Lelakimasakini (Analisis Semiotika Roland Barthes Terhadap Representasi Maskulinitas)

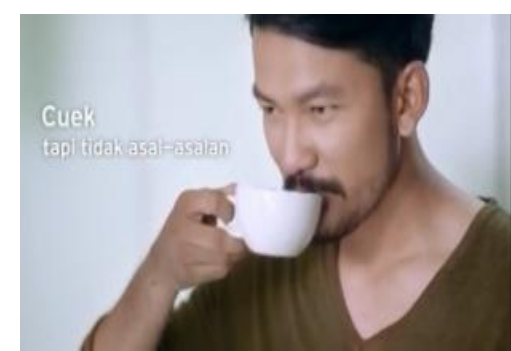

Gambar 3: Scene 3 Iklan Versi Rio Dewanto

Makna denotatif: Dapat diuraikan, petanda yang berada dalam potongan iklan di atas ialah tertera tulisan "Cuek tapi tidak asal-asalan...", di sebuah dapur, tersenyum sambil memegang secangkir kopi dengan tatapan menghadap kedepan, wajah dipenuhi oleh kumis dan janggut tipis, serta rambut rapih dan cepak, memakai $t$-shirt model v-neck.

Makna Konotasi: Lelaki masa kini adalah lelaki yang detail dan rapi. Screen shoot dalam iklan ini menampilkan makna maskulinitas dengan pribadi laki-laki yang cuek namun tetap detail. Media menampilkan sisi lain dari sifat laki-laki pada umumnya yang cuek, namun disini media mengambil sisi laki-laki yang cuek tapi tidak asal-asalan dalam bertindak. Wanita akan merasa senang apabila ia diperhatikan oleh pasangannya dan mereka menginginkan laki-laki yang memperhatikan mereka.

Mitos: Lelaki memiliki sifat yang detail. Laki-laki yang tidak asal-asalan dalam kecuekannya ialah laki-laki yang selalu memberikan kejutan kecil. Meskipun ia memiliki sifat yang cuek tapi, sebenarnya ia memperhatikan lingkungan sekitar hanya penyampaiannya saja yang tidak biasa. Bila laki-laki dengan sifat cuek ini menunjukkan perhatian maka pasangannya susah untuk melupakan perhatian yang diberi. Itulah yang coba iklan ini berikan kepada khalayak bahwa laki-laki yang cuek itu tidak asal-asalan, karena ia pun harus tahu waktu mana yang tepat untuk memberikan waktunya pada pasangannya.

Detail pun terlihat dari bagaimana model berpakaian atau berpenampilan. Biasanya laki-laki cuek dengan penampilannya namun, di sini Rio Dewanto menyampaikan pesan jika laki-laki masa kini harus memperhatikan penampilannya, bukan karena tuntutan namun, demi kenyamanan diri sendiri juga. Tampilan yang rapi dipresentasikan oleh Rio melalui cara berpakaian, cara merawat wajah dan lainnya. Laki-laki dengan tipe ini termasuk ke dalam maskulin era 1900-an yang cuek tapi masuk juga ke era maskulin 2000-an yang memperhatikan penampilannya.

POND'S Men \#LelakiMasaKini versi Keenan Pearce

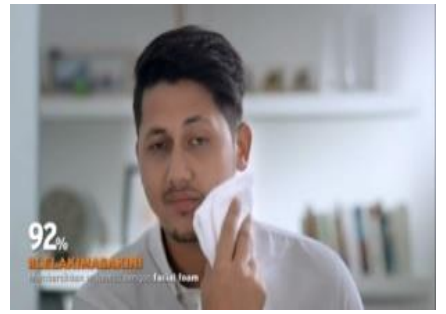

Gambar 4: Scene 1 Iklan Versi Keenan Pearce 
Makna denotasi: Dapat diuraikan, petanda yang berada dalam potongan iklan diatas ialah seorang lelaki yang sedang mengusap wajahnya dengan handuk berwarna putih melihat ke arah cermin, terdapat tulisan "92\% \#LelakiMasaKini membersihkan wajahnya dengan facial foam”, menggunakan kameja warna putih, berambut pendek dengan model undercut blow pomp, dan memiliki kumis tipis serta janggut, serta bertampang "indo".

Makna konotasi: Lelaki masa kini diidentikan dengan tampang "indo". Media sendiri biasanya mencari model yang memiliki tampang "indo" karena, wajah-wajah ini menjadi idola dunia hiburan dan ikon majalah populer serta menjadi primadona beberapa produsen iklan yang tidak hanya menjual produk tetapi juga sekaligus memasarkan gambaran tentang kecantikan, ketampanan, dan tubuh yang ideal ke masyarakat konsumen Indonesia. Dengan memiliki tampang "indo" untuk laki-laki sudah mewakili citra tubuh yang tinggi, berkulit putih, dan berhidung mancung.

Mitos: Lelaki masa kini diidentikan dengan tampang "indo". Gambaran maskulinitas yang ditawarkan dalam iklan ini adalah seorang laki-laki yang sedang mengelap wajahnya dengan sebuah handuk dan sedang berkaca. Dengan cara yang tidak langsung, produsen pemasaran menggambarkan sedikit dari kebiasaan laki-laki modern, yang memperhatikan wajahnya sebelum pergi beraktifitas. (Stritanti,2003).

Media memunculkan berbagai karakter maskulinitas dari mulai perawakan, khususnya wajah lalu kepribadian dari si model. Maskulinitas yang ditampilkan di media ialah memiliki kejantanan, ketangkasan, keperkasaan, keteguhan hati, hingga otot-otot yang diperlihatkan di dalam iklan. Model yang memiliki tampang "indo" biasanya mendapatkan tempat untuk tampil di berbagai iklan, termasuk iklan produk perawatan wajah seperti ini. Model yang memiliki tampang "indo" dicerminkan sebagai laki-laki yang memiliki tampang yang cocok karena wajahnya yang kebule-bulean dan berparas tampan. Namun, hal tersebut tidak mengurangi kemaskulinan yang dimiliki oleh model ini.

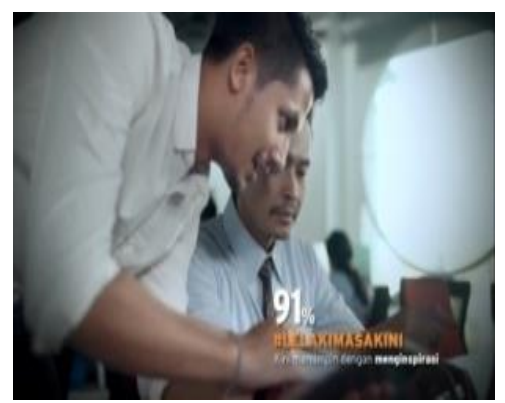

Gambar 5: Scene 2 Iklan Versi Keenan Pearce

Makna denotasi: Dapat diuraikan, petanda yang berada dalam potongan iklan di atas ialah terdapat tulisan "91\% \#LelakiMasaKini memimpin dengan menginspirasi”, lelaki dengan tampilan rapi, sedang bekerja, di sebuah kantor.

Makna konotasi: Lelaki masa kini adalah lelaki yang tegas dalam memimpin dan siap bekerja. Keenan Pearce menggambarkan menjadi salah satu pemimpin yang siapa bekerja. Hal ini ditandai dengan terlihatnya gulungan lengan 
Friska Dewi Yuliyanti, Atwar Bajari, Slamet Mulyana: Representasi Maskulinitas Dalam Iklan Televisi Pond's Men \#Lelakimasakini (Analisis Semiotika Roland Barthes Terhadap Representasi Maskulinitas)

kameja yang dipakainya saat bekerja. Simbol tersebut diartikan sebagai salah satu artian untuk siap bekerja. Seseorang yang siap untuk bekerja biasanya menggulung lengan bajunya untuk mengerjakan sesuatu.

Harian Barometer Rakyat edisi 15 September 2015 menyatakan, bahwa lengan baju digulung, memiliki makna pekerja keras, dan semangat tinggi menyelesaikan pekerjaan. Biasanya ini dilakukan agar kepercayaan diri lebih tinggi dan sigap dalam kondisi apapun.

Mitos: Lelaki masa kini adalah lelaki yang tegas dalam memimpin dan siap bekerja. Dalam konteks ini, terlihat dengan jelas konsep hegemoni maskulinitas. Artinya, ada bentuk kekuasaan disana yang merujuk pada titik siapa yang menjadi atasan dan karyawan biasa. Dalam sebuah konsep maskulin terdapat istilah Be a Big Wheel, yaitu maskulinitas yang diukur dari kekuasaan atau kekuatan yang dimiliki tingkat kesuksesan tingkat kesejahteraan, dan status yang dimiliki.

Menjadi sifat dasar seorang laki-laki memiliki kekuasaan atas orang lain atau sekitarnya dan rasa tidak puas dari apa yang dicapai. Menjadi pemimpin dalam sebuah perusahaan haruslah tegas namun, tidak berarti harus kasar dengan melontarkan kata-kata kasar kepada karyawannya. Sisi tegas bagi pemimpin harus dimiliki, terutama oleh laki-laki. Bagi kaum hawa tentunya laki-laki yang memiliki sifat tegas adalah pujaan hati karena, biasanya perempuan ingin mencari imam yang dapat membimbing dirinya nanti.

Laki-laki maskulinpun harus siap bekerja untuk kehidupannya dan kewajibannya sebagai pencari nafkah. Simbol maskulinitas tersebut sangat terlihat dari Keenan Pearce menggulung lengan bajunya yang berarti pekerja keras dengan memiliki semangat yang tinggi untuk segera menyelesaikan suatu pekerjaan.

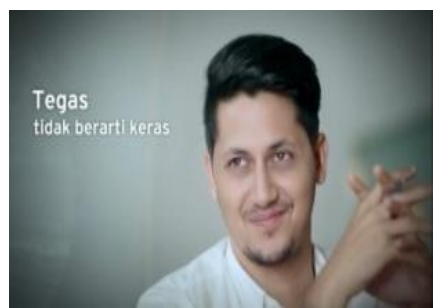

Gambar 6: Scene 3 Iklan Versi Keenan Pearce

Makna denotasi: Dapat diuraikan petanda yang berada dalam potongan iklan diatas ialah di dalam screen ini terlihat Keenan Pierce yang sedang tersenyum dengan posisi duduk, ditambah dengan tulisan di layar yaitu "Tegas tidak berarti kasar", berada disebuah ruangan presentasi.

Makna konotasi: Lelaki masa kini adalah lelaki yang memimpin dengan percaya diri. Percaya diri tentunya saja harus dimiliki oleh setiap pemimpin agar bisa mempengaruhi karyawannya untuk bekerja lebih baik, mempunyai semangat yang lebih tinggi dalam memimpin dan selalu optimis dalam menjalani semua hal seperti projek pekerjaan baru dan lainnya. Media menampilkan sosok yang percaya diri di televisi dengan tujuan agar pesan positif 
yang dilakukan oleh model iklan bisa didapat oleh para khalayak yang melihatnya.

Mitos: Lelaki masa kini adalah lelaki yang memimpin dengan percaya diri. Gambaran maskulinitas yang ditawarkan dalam iklan ini adalah seorang lakilaki yang berada di sebuah kantor, tersenyum dengan percaya diri serta menyimak presentasi rekannya. Lelaki yang dikatakan maskulin adalah lelaki yang memiliki rasa percaya diri dan jujur. Di mata perempuan, laki-laki yang kurang percaya diri bukanlah laki-laki yang sejati. Percaya diri dan menerima apa adanya, itulah yang menjadi daya tarik (Savitri, 2011).

Lelaki yang dikatakan maskulin adalah lelaki yang memiliki rasa percaya diri dan jujur. Di mata perempuan, laki-laki yang kurang percaya diri bukanlah laki-laki yang sejati. Percaya diri dan menerima apa adanya, itulah yang menjadi daya tarik (Savitri, 2011). Laki-laki akan merasa menjadi sangat sensitif ketika laki-laki merasa tidak mampu memenuhi prasyarat maskulinitas dalam peran gendernya ia akan merasa malu dan terhina karena merasa harga dirinya jatuh serta merasa hidupnya menjadi tidak bermakna lagi. Harga diri inilah yang menjadi ketakutan bagi kaum adam sehingga mereka akan menjaga dan mempertahankannya. Maka, dibutuhkanlah rasa percaya diri untuk memimpin dalam diri seorang laki-laki yang maskulin.

\section{POND'S Men \#LelakiMasaKini versi Marshall Sastra}

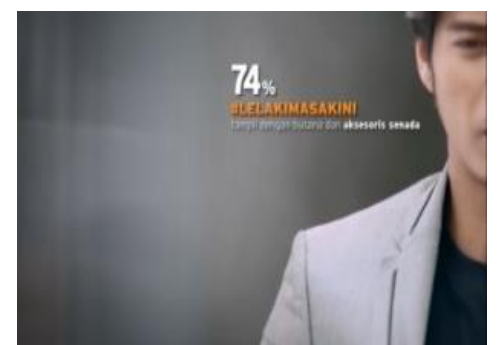

Gambar 7: Scene 1 Iklan Versi Marshall Sastra

Makna denotasi: Dapat diuraikan bahwa petanda yang berada dalam potongan iklan diatas ialah di layar terdapat tulisan "74\% \#LelakiMasaKini tampil dengan busana dan aksesoris senanda", terlihat potongan tubuh laki-laki dengan menggunakan pakaian casual yaitu $t$-shirt dan jas, dan rambut pendek rapi.

Makna konotasi: Lelaki masa kini adalah lelaki yang memperhatikan penampilan. Screen shoot dalam iklan ini menampilkan makna lelaki masa kini yang memiliki perhatian pada penampilannya dan mengerti tentang gaya. Meskipun sebagai laki-laki namun, setidaknya harus memperhatikan penampilan sebagai modal utama untuk memikat perhatian. Lelaki akan merasa bangga jika penampilannya dapat memikat perhatian, terutama pada lawan jenis. Kesan maskulin dan stylish dari Marshall Sastra pada iklan ini didukung dengan penampilan pakiannya yang digunakan, yaitu menggunakan warna-warna yang netral sebagai penanda laki-laki dewasa yang menyukai warna-warna gelap. Seperti warna hitam pada $t$-shirt yang digunakannya. 
Friska Dewi Yuliyanti, Atwar Bajari, Slamet Mulyana: Representasi Maskulinitas Dalam Iklan Televisi Pond's Men \#Lelakimasakini (Analisis Semiotika Roland Barthes Terhadap Representasi Maskulinitas)

Mitos: Lelaki masa kini adalah lelaki yang memperhatikan penampilan. Walaupun laki-laki terkadang cuek dengan penampilannya yang cukup rapi dan memperhatikan penampilan asalkan tidak berlebihan sekali. Sebagai seorang muslim diperintahkan agar berpakaian rapi dan sopan sesuai tuntunan syariat. Selain itu, laki-laki dengan memiliki tubuh yang wangipun memiliki magnet tersendiri, khususnya untuk perempuan. Perempuan akan merasa nyaman jika duduk, atau berdampingan dengan laki-laki yang wangi. Tidak ada salahnya jika laki-laki berpenampilan gaya namun, sesuai dengan porsinya dan tetap terlihat maskulin.

Maskulinitas pada tahun 1980-an juga memiliki ciri seperti ini, yaitu memiliki penampilan yang flamboyan dan perlente. Pada era ini, banyak produkproduk komersil untuk laki-laki yang bermunculan, bahkan laki-laki sebagai objek seksual yang menjadi bisnis amat luar biasa. Pergeseran maskulinitas bergulir dengan banyaknya perkembangan namun, pada tahun 2000-an kembali muncul laki-laki maskulin yang memperhatikan penampilan dari ujung kepala hingga ujung kaki.

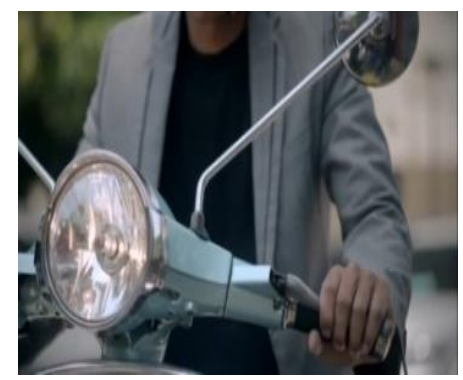

Gambar 8: Scene 2 Iklan Versi Marshall Sastra

Makna denotasi: Dapat diuraikan, petanda yang berada dalam potongan iklan di atas ialah model mengendarai sebuah motor vespa, dengan menggunakan setelan yang rapi.

Makna konotasi: Lelaki masa kini adalah lelaki yang tertarik pada otomotif. Screen shoot iklan ini menampilkan makna lelaki masa kini yang memiliki ketertarikan pada dunia otomotif. Dunia otomotif tentu saja tidak lepas dari laki-laki. Banyak laki-laki yang memiliki hobi dengan otomotif, yaitu mobil ataupun motor. Mereka akan merasa bangga ketika mengendarai kendaraan kesayangannya yang terlihat bagus dan beda dari pada orang lain. Karena sebagian laki-laki secara sengaja menyisihkan uangnya untuk kegiatan otomotif seperti modifikasi, membeli aksesoris, perawatan kendaraan dan lainnya. Tidak sedikit juga para laki-laki ini mengeluarkan budget yang besar untuk hobinya.

Mitos: Lelaki masa kini adalah laki-laki yang cinta dengan hobinya. Sebuah hobi bukan saja menjadi sarana untuk bertukar pikiran dengan teman yang memiliki selera yang sama melainkan disisi lain ialah menarik perhatian lawan jenis karena perempuan suka laki-laki yang gemar "memamerkan" hobinya dan bepergian ke mana-mana karena hobi itu. Beberapa hobi sangat menarik untuk beberapa tipe perempuan, selama laki-laki tersebut melakukan dengan sungguhsungguh. 
Otomotif dengan laki-laki menjadikan mereka sebuah kesatuan. Karena tidak sedikit laki-laki yang memiliki hobi di bidang ini. Jika melihat laki-laki dengan motor "gede" yang dikendarainya maka, akan menarik perhatian siapapun terutama kaum hawa. Bagi mereka yang menyukai laki-laki dengan motor "gede" maka, akan terlintas dipikirannya jika, laki-laki tersebut merupakan laki-laki yang maskulin sekali.

Laki-laki yang memiliki hobi seperti ini biasanya terkumpul ke dalam sebuah kelompok yang memiliki hobi, selera yang sama pula. Tipe laki-laki maskulin seperti ini masuk ke dalam maskulinitas tahun 2000-an yang berasal dari kalangan menengah atas, dan juga tergabung dalam sebuah komunitas yang terpandang dalam masyarakat seperti, kelompok penyuka otomotif ini. Memang sangat terlihat maskulin jika laki-laki bergaul dengan otomotif

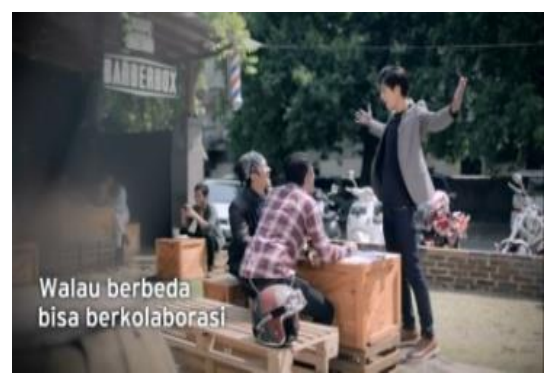

Gambar 9: Scene 3 Iklan Versi Marshall Sastra

Makna denotasi: Dapat diuraikan, petanda yang berada dalam potongan iklan diatas ialah pada layar terdapat tulisan "Walau berbeda bisa bekrolaborasi”, model mengunjungi sebuah tempat nongkrong, dan menyapa teman-temannya dengan bahagia.

Makna konotasi: Lelaki masa kini adalah lelaki yang bisa mengendalikan situasi, memiliki pertemanan yang luas dan berpikir maju. Lelaki masa kini adalah lelaki yang mampu mengendalikan situasi, misalnya pada saat pertama kali bergabung dalam sebuah kelompok dan kelompok tersebut memiliki kepribadian yang berbeda, lalu ia memiliki ide untuk membuat situasi tidak tegang. Salah satunya ialah membicarakan soal hobi. Hobi yang digambarkan pada screen shoot adalah soal otomotif, yaitu bagaimana memodifikasi kendaraan. Sebagai yang memiliki ide Marshall Sastra harus berpikiran terbuka agar semua ide dapat tertampung dan membuat ide baru yang menyatukan berbagai perbedaan menjadi satu ide yang baru.

Mitos: Lelaki masa kini adalah lelaki yang supel. Berkumpul bersama teman atau kolega, berbicara tentang pekerjaan, hobi, dan lelucon-lelucon untuk menghidupkan suasana adalah gambaran pada ilustrasi iklan diatas. Hal ini, membuktikan bahwa bentuk laki-laki yang dipromosikan dalam iklan adalah mereka yang menikmati hidup dengan dikelilingi oleh teman atau kolega. Konsep maskulinitas pada laki-laki memiliki banyak jenis tergantung bagaimana ia berkelakuan. Pada cuplikan iklan ini jika dilihat dari konsep maskulinitas dari Connell, 2000 (dalam Ramadhan, 2012) termasuk kedalam maskulinitas yang memiliki sifat ideal Collective masculinities, yaitu laki-laki harus berperilaku maskulin sehingga maskulinitas menjadi karakteristik individu. Maskulinitas 
Friska Dewi Yuliyanti, Atwar Bajari, Slamet Mulyana: Representasi Maskulinitas Dalam Iklan Televisi Pond's Men \#Lelakimasakini (Analisis Semiotika Roland Barthes Terhadap Representasi Maskulinitas)

didefinisikan secara kolektif seperti di tempat kerja taupun kelompok informasi seperti peer group.

Lelaki maskulin dalam cuplikan iklan ini dapat dilihat dari bagaimana cara berpikir yang ia miliki, karena seorang lelaki yang bisa dibilang dewasa harus mampu bersikap bijaksana dan mengurangi rasa egonya ketika harus dihadapkan dengan perbedaan seperti pada iklan di atas. Meskipun banyak perbedaan dengan adanya selara masing-masing dari setiap individu dalam kelompok namun, ia harus bisa memecahkan masalahnya dan memberikan inovasi atau solusi baru yang sama sekali tidak memihak salah satu orang. Dalam relasi sosial pada lingkungan masyarakat sehari-hari, laki-laki mampu menjadi figur yang menjembatani antara dunia internal dengan lingkungan sosial (Chairunissa, 2013).

\section{Ideologi Maskulinitas Melalui Iklan}

Ideologi merupakan sebuah istilah yang digunakan untuk melukiskan produksi sosial atas makna. Penelitian ini menggunakan pemikiran ideologi Althusser, hegemoni Gramsci, serta sedikit tentang teori struktural-fungsional dalam menganalisis konsep iklan dan maskulinitas pada iklan POND'S Men edisi \#LelakiMasaKini pada tiga versi ini. Penulis mengajukan tiga hubungan antara ideologi, hegemoni, dan teori postmodern sebagai pendukung. Penulis menganalisis gambaran maskulinitas dari iklan perawatan wajah tersebut yang masih memiliki karakter maskulin atau tidak.

Menurut Altahusser dalam (Strinati, 2007) ideologi tidak mencerminkan dunia real bahwa ideologi dipersepsikan sebagai realitas kesadaran palsu. Ideologi merepresentasikan "hubungan-hubungan imajiner" individu-individu terhadap dunia real. Ideologi diformulasikan oleh Althusser ke dalam dua karakteristik. Pertama, ketika idelogi terikat pada sebuah analisis instituasional, ini tidak dapat dipahami sebagai pembalikan atau refleksi dari yang real. Ideologi lebih dipahami sebagai 'represent the imaginary relationship of individuals of their real condition of exstence'. Kedua, ideologi tidak hanya merupakan hubungan simbolik dengan yang real, tapi mengubah human being menjadi subjek-subjek. Ideologi membiarkan individu-individu mengenali secara salah diri mereka sendiri sebagai self-determining agents, kenyataannya subjek-subjek dibentuk melalui proses linguistik dan psikis. Subjek menyalah kenali diri mereka sendiri sebagai individu yang unik daripada sebuah konstruksi identitas melalui proses sosial (Stevenson, dalam Chairunissa, 2013).

Ideologi bekerja melalui konstruk sosial untuk proses subjek individual dan kolektif dari keseluruhan identifikasi dan pengetahuan yang ditransmisikan dalam nilai-nilai ideologis. Ini berarti proses kekuasaan dan dominasi tidak hanya bersifat material tapi juga bersifat kultural. Dominasi yang bersifat immaterial tersebut meliputi perluasan dan pelestarian "kekuasaan sukarela" dari kelompok yang didominasi oleh kelas elit penguasa melalui pemanfaatan kekuasaan intelektual, moran dan politik. Melalui hegemoni, penyebaran (distribusi) ide, nilai, belief system, dipenetrasikan secara "seakan-akan wajar". Dalam arti tertentu, ideologi yang hegemonik mengaidahkan percampuran dengan praksis sosial. 
Tanda-tanda memberi mitos dan nilai bentuk yang konkret dan dengan cara demikian keduanya mengabsahkan dan membuat tanda menjadi bersifat publik. Tatkala tanda membuat mitos dan nilai menjadi publik, maka tanda memungkinkan mitos dan nilai menjalankan fungsi identifikasi kultural yakni, memungkinkan anggota suatu kebudayaan tersebut melalui penerimaan mitos dan nilai-nilai bersama (Fiske, dalam Sopianah, 2010).

Konstruksi hasil penelitian ini adalah ditemukannya sebuah ide tentang karakteristik maskulinitas yang terdapat dalam iklan POND'S Men edisi \#LelakiMasaKini dalam tiga versi, penulis bisa melihat bahwa dalam iklan POND'S Men terdapat karakteristik new masculinity. Akhir tahun 1900-an menuju tahun 2000-an munculah istilah baru dalam konstruksi diri laki-laki yaitu new masculinity (konsep maskulinitas baru). Sosok baru ini menyajikan sebuah paduan unik dan menarik yang membuka mata dunia atas stereotype imaji maskulin yang selama ini dibentuk. Karakter maskulinitas ini berbeda dengan maksulinitas pendahulunya.

Media merupakan salah satu sarana yang berperan dalam pencitraan maskulinitas. Melalui media berbagai pihak berupaya memberikan gambaran mengenai konsep maskulinitas. Dalam media vidual tubuh laki-laki merupakan sebuah kendaraan yang penuh makna. Melalui visual tubuh laki-laki ditunjukkan melalui fisik dan pakaiannya. Dengan seiringnya zaman berkembang saat ini, banyak sekali produk perawatan laki-laki yang datang ke layar kaca untuk merepresentasikan maskulin sesuai dengan produk yang dipasarkan. Jika dilihat, objek penelitian yang dilakukan rata-rata model dalam iklan produk perawatan wajah khusus untuk laki-laki POND'S Men edisi \#LelakiMasaKini menggambarkan konsep maskulinitas baru yang disebut dengan metroseksual.

Iklan produk perawatan wajah khusus untuk laki-laki ini rata-rata memiliki karakteristik maskulinitas baru (new masculinity) karena adanya sisik feminitas di dalamnya. Terbukti di dalam iklan POND'S Men ini masih memiliki karakteristik maskulin namun, tidak seperti maskulin tradisional yang menampilkan otot, keringat dan kekuatan. Kemaskulinitasan didalam iklan ini digambarkan sebagai laki-laki yang rapi, sukses, sensitif dengan perasaan perempuan, mengerti hobi dan lainnya. Inilah sosok yang diinginkan oleh para perempuan khususnya. Mereka menyakini bahwa sosok laki-laki yang seperti ini adalah sosok yang baik tidak seperti laki-laki yang macho yang hobinya mempermainkan perasaan.

Pada konsep maskulinitas baru atau metroseksual ditampilkan pada iklan yaitu, untuk mempertegas orientasi seksual laki-laki dalam iklan, ditampilkan sisi perempuan yang merasa tersanjung karena telah diperlakukan dengan baik, menggunakan kekuasaannya sebagai pemimpin namun tidak kasar dan menampilkan sisi maskulinnya dengan hobi otomotif. Di sisi lain, mereka juga menggunakan produk perawatan wajah agar tetap terlihat segar dan demi menambah rasa percaya diri sehingga jelas bahwa lelaki masa kini adalah lelaki yang metrosekssual yang suka merawat diri dengan tujuan untuk menambah rasa percaya diri dan selalu terlihat bersemangat. 
Friska Dewi Yuliyanti, Atwar Bajari, Slamet Mulyana: Representasi Maskulinitas Dalam Iklan Televisi Pond's Men \#Lelakimasakini (Analisis Semiotika Roland Barthes Terhadap Representasi Maskulinitas)

\section{Simpulan}

Berdasarkan hasil penelitian yang dilakukan pada tiga versi iklan POND'S Men \#LelakiMasaKini ini, maka dapat disimpulkan bahwa:

1. Makna denotasi merupakan tingkatan pertama yang dapat dianalisis dari ketiga tingkatan semiotika Roland Barthes. Berdasarkan tanda-tanda dominan yang muncul pada ketiga versi iklan POND'S Men \#LelakiMasaKini, telah ditemukan sembilan makna denotasi berdasarkan veris masing-masing pada beberapa scene setiap versi iklan. Makna denotasi yang ditemukan pada iklan tersebut bersifat langsung.

2. Makna konotasi merupakan tingkatan kedua yaitu, tingkatan yang melihat makna lebih dalam serta mengungkap makna yang tersembunyi dibalik tanda-tanda yang dapat dianalisis dari ketiga tingkatan semiotika Roland Barthes. Penelitian telah menunjukkan makna konotasi dari berbagai adegan yang telah dipilih melalui ketiga versi iklan POND'S Men \#LelakiMasaKini. Makna-makna konotasi yang ditemukan merupakan makna yang mengungkapkan dan memberikan pembenaran terhadap adanya nilai-nilai dominan yang berlaku dalam satu periode tertentu.

3. Mitos merupakan sebuah sistem yang unik. Mitos yang terbangun di dalam iklan POND'S Men \#LelakiMasaKini terbagi kedalam tiga versi yang berbeda. Versi pertama menambah rasa peracaya diri setelah mencuci muka dan lelaki yang perhatian. Versi kedua yaitu lelaki diidentikan dengan tampang 'indo, tegas dan siap bekerja dan seorang pemimpin. Versi ketiga yaitu lelaki masa kini adalah lelaki yang memperhatikan penampilan, cinta dengan hobinya dan supel.

4. Konstruksi ideologi yang dibangun dalm iklan yang dianalisis adalah terbentuknya karakteristik new masculinity.

Saran yang diberikan berdasarkan penelitian yang dilakukan adalah sebagi berikut:

1. Penelitian ini hanya membatasi analisis pada level teks, yaitu bagaimana televisi merepresentasikan ideologi maskulinitas. Diharapkan penelitian yang akan datang dapat meneliti aspek lain yakni dalam bidang media dan khususnya dalam metode semiotika.

2. Penelitian yang akan datang juga dapat menganalisis pengaruh gambaran maskulinitas pada iklan produk perawatan laki-laki pada keseharian lakilaki sebenarnya dan sebaiknya penelitian selanjutnya menyingkap berbagai tanda dan makna akan gambaran berbagai tipe maskulinitas di dalam berbagai media agar bisa dibedakan karakter maskulinitas di media satu dengan media yang lainnya, khususnya media massa. 


\section{Ucapan Terima Kasih}

Penulis mengucapakn rasa terima kasih yang sebesar-besarnya kepada seluruh pihak yang telah membantu dan mendukung penulis selama proses penelitian ini berlangsung sampai dengan terbitnya publikasi atas hasil penelitian ini.

\section{Daftar Pustaka}

Chairunissa. (2013). Representation of Masculinity Men, Roland Barthes Semiotics Analysis Representation Of Masculinity in Two Men Face Care Advertising Product. Theses, Faculty of Communication Sciences, University of Padjadjaran.

Kusumastutie, Srie., \& Faturochman. (2004). Semiotika Untuk Gender Pada Iklan Televisi, Buletin Psikologi, Nomor. 2, 130-141. https://jurnal.ugm.ac.id/buletinpsikologi/article/view/7473

Savitri, Dian. (April 18, 2011). 10 Syarat Menjadi Laki-laki Maskulin. Juni 19, 2016.

http://health.kompas.com/read/2011/04/18/10023096/10.syarat.jadi.lakilaki.maskulin

Sopianah, Siti. (n.d.). Analisis Semiotika Terhadap Iklan Susu Bendera Edisi Ramadhan 143 di Televisi. Mei 3, 2017. Skripsi, UIN Jakarta. http://repository.uinjkt.ac.id/dspace/bitstream/123456789/957/1/SITI\%20S OPIANAH-FDK.pdf

Strinati, D. (2003). Popular Culture Pengantar Menuju Teori Budaya Populer. Yogyakarta: Jalasutra.

Triwidiastyty, Syifa., \& Kahija, Yohanis Franz La. (2015). Memahami Makna Menjadi Laki-laki Metroseksual. Jurnal Empati, 4 (2), 58-64. Mei 3, 2017. http://download.portalgaruda.org/article.php?article=473275\&val=4725\&t itle=MEMAHAMI\%20MAKNA\%20MENJADI\%20LAKILAKI\%20METROSEKSUAL

Unilever. (2013). Ponds Jadikan Laki-Laki Indonesia Cerah dan Berenergi. November 30, 2011. http://www.unilever.co.id/id/mediacentre/pressreleases/2013/Ponds-Jadikan-Laki-laki-Indonesia-Cerah-DanBerenergi.aspx. 